\title{
Weight of all births and infant mortality
}

\author{
L. FEGERSTEN SAUGSTAD \\ From the Institute of Occupational Health, Oslo, Norway
}

SUMMARY Birth weight is the most important determinant of perinatal and infant mortality. The lowest mortality rates in the first week of life are recorded among newborn infants weighing $3500 \mathrm{~g}$ or more and the proportion of such infants may be regarded as a measure of optimality of the birth population. There is an inverse relationship between the proportion of heavy newborn infants in a country and its infant mortality rate. In both these respects Iceland, Norway, and Sweden have a better experience than England and Wales, Denmark, and the United States of America. The effects of parity, maternal age, social class, and smoking are considered, but it appears that there are still factors that inhibit the intrauterine growth potential of American, British, and Danish fetuses. Elective delivery, use of diuretics, and restriction of diet in pregnancy have shifted the birth distribution to the left and this may have more than counterbalanced the possible beneficial effects.

These other factors may adversely affect birthweight distribution in North America and Europe to such an extent as to limit or even damage the favourable position already achieved in health and social development as measured by fetal survival.

Neonatal mortality is strongly dependent on birth weight. In Scandinavia today about half of the infants weighing less than $1500 \mathrm{~g}$ at birth die during the first week of life compared with less than $5 \%$ of infants weighing between 1501 and $2500 \mathrm{~g}$, about $0.5 \%$ of those between 2501 and $3000 \mathrm{~g}$, and approximately only one in 1000 of those weighing more than $3500 \mathrm{~g}$ (Table 1). Discussion on how to reduce infant and neonatal mortality has therefore centred upon the reduction of the proportion of infants with a birth weight lower than $2500 \mathrm{~g}$. But it should be noted that mortality is lowest in quite large babies, between $3501 \mathrm{~g}$ and $4500 \mathrm{~g}$ or $5000 \mathrm{~g}$; and even in the heaviest group, over $4500 \mathrm{~g}$ or $5000 \mathrm{~g}$, mortality is only slightly higher. Consequently, any factor which

Table 1 Early neonatal mortality (\%) by birth weight in Norway, Sweden, and Denmark

\begin{tabular}{lccc}
\hline $\begin{array}{l}\text { Birth weight } \\
(\mathrm{g})\end{array}$ & $\begin{array}{l}\text { Sweden } \\
1973\end{array}$ & $\begin{array}{l}\text { Denmark } \\
1974\end{array}$ & $\begin{array}{l}\text { Norway } \\
1975-6\end{array}$ \\
\hline Under 1500 & $45 \cdot 8$ & $46 \cdot 4$ & $55 \cdot 0$ \\
$1501-2500$ & $4 \cdot 6$ & $3 \cdot 3$ & 3.5 \\
$2501-3000$ & 0.47 & 0.43 & 0.43 \\
$3001-3500$ & $0 \cdot 18$ & $0 \cdot 14$ & $0 \cdot 15$ \\
$3501-5000$ & 0.11 & $0 \cdot 10$ & $0 \cdot 09^{*}$ \\
Over 5000 & 0.20 & - & $0 \cdot 18$ \\
\hline
\end{tabular}

Information for latest available year derived from the National Central Bureaux of Statistics in Norway, Denmark, and Sweden.

*Birthweight interval 3501-4500 g reduces birth weight, even if it does not increase the proportion of births under $2500 \mathrm{~g}$, may increase first-week deaths.

In this paper, national figures of the distribution of birth weights in selected countries are examined and compared with infant mortality rates, and trends and patterns that may affect these results are investigated.

\section{Materials and methods}

Information on the distribution of birth weight, of maternal age and parity, of infant mortality and first-week deaths was obtained from the United Nations Demographic Yearbook $1975^{1}$ and from various official national publications. ${ }^{2-24}$

In the present investigation, the choice of infant mortality instead of perinatal mortality was influenced by the fact that in Scandinavia stillbirth rates are not directly comparable. Norway, Sweden, and Denmark have all adopted the World Health Organisation criteria of live birth and fetal death, but the three countries differ in their practices. As a result, the proportions of extremely low-birthweight stillborn infants vary. In $1974,9 \%$ of the Norwegian stillborn infants weighed less than $1000 \mathrm{~g}, 6 \cdot 6 \%$ of the Swedish, but only $1.5 \%$ of the Danish. Moreover, in Norway, infant mortality is inflated by the 185 
weight which previously would have been classified as stillborn or abortions. Between 1969 and 1972, some $20 \%$ of the first-week deaths weighed less than $1000 \mathrm{~g}$ and $70 \%$ of these died during the first 24 hours. On the assumption that these non-viable infants would have been classified as abortions or stillborn in Sweden, infant mortality in Norway in 1978 would be reduced from the observed 8.6 to 7.9 per 1000 births.

\section{Results}

Table 2 shows the proportion of births in five weight groups together with the infant mortality rate for 13 selected countries in about 1973 . The countries are ranked in order according to the proportion of births over $3500 \mathrm{~g}$. The highest proportion of these births occurred in Iceland and the Faeroes, where the lowest proportion of births under $2501 \mathrm{~g}$ was also recorded. In Norway and Sweden the frequency of low birth weight is higher but the infant mortality rate remains low. Western Germany, Czechoslovakia, and Denmark have similar birthweight distributions, but very different infant mortality rates $(21.1$ in Germany, 20.4 in Czechoslovakia, and 10.4 in Denmark).

The proportion of heavy babies is lower and that of light babies higher in the USA, Canada, and the United Kingdom, and the infant mortality rates are similar. In Poland and Hungary there is a further shift to the left of the weight distribution and a corresponding increase in mortality.

Japan is exceptional in that although the proportion of births over $3500 \mathrm{~g}$ is only $23 \cdot 3 \%$, the

Table 2 Proportion of births by weight and infant mortality rates in certain countries (\%)

\begin{tabular}{|c|c|c|c|c|c|c|c|}
\hline Country & Year & $<2500_{g}$ & $2501-3000 \mathrm{~g}$ & $3001-3500 \mathrm{~g}$ & $3501-4000 \mathrm{~g}$. & $>4000 \mathrm{~g}$ & $\begin{array}{l}\text { Infant mortality } \\
\text { per } 1000\end{array}$ \\
\hline FAEROES & 1973 & 3.7 & $8 \cdot 3$ & $26 \cdot 6$ & 38.0 & 23.4 & $12 \cdot 8$ \\
\hline ICELAND & 1972 & $4 \cdot 3$ & $8 \cdot 7$ & $28 \cdot 2$ & $35 \cdot 2$ & 23.6 & $10 \cdot 1$ \\
\hline NORWAY & $1972-4$ & $4 \cdot 4$ & $11 \cdot 7$ & 32.9 & $34 \cdot 3$ & $16 \cdot 7$ & $10 \cdot 4$ \\
\hline SWEDEN & 1973 & $4 \cdot 6$ & 11.9 & $34 \cdot 0$ & $33 \cdot 7$ & $15 \cdot 8$ & $8 \cdot 6$ \\
\hline GERMANY GFR** & 1973 & 6.7 & $14 \cdot 6$ & $38 \cdot 3$ & $29 \cdot 7$ & $10 \cdot 7$ & $21 \cdot 1$ \\
\hline DENMARK & $1973-4$ & 6.8 & $17 \cdot 6$ & $37 \cdot 1$ & $28 \cdot 5$ & $10 \cdot 0$ & $10 \cdot 7$ \\
\hline CZECHOSLOVAKIA ** & 1973 & $6 \cdot 1$ & $17 \cdot 1$ & $39 \cdot 0$ & $28 \cdot 8$ & $9 \cdot 0$ & $20 \cdot 4$ \\
\hline USA & 1973 & $7 \cdot 6$ & $18 \cdot 2$ & $38 \cdot 2$ & $27 \cdot 0$ & $9 \cdot 0$ & $17 \cdot 7$ \\
\hline CANADA** & 1973 & $7 \cdot 0$ & $18 \cdot 7$ & $39 \cdot 1$ & 26.9 & $8 \cdot 3$ & $15 \cdot 0$ \\
\hline UNITED KINGDOM & 1970 & 6.8 & $18 \cdot 9$ & $39 \cdot 1$ & $26 \cdot 8$ & $8 \cdot 3$ & $16 \cdot 4$ \\
\hline POLAND** & 1974 & $8 \cdot 0$ & $19 \cdot 7$ & $37 \cdot 3$ & $26 \cdot 7$ & $8 \cdot 3$ & $23 \cdot 5$ \\
\hline HUNGARY** & 1974 & $11 \cdot 7$ & 23.4 & 38.0 & $21 \cdot 4$ & $5 \cdot 5$ & $34 \cdot 3$ \\
\hline JAPAN** & 1974 & $5 \cdot 1$ & $25 \cdot 0$ & 46.6 & $20 \cdot 1$ & $3 \cdot 2$ & $10 \cdot 8$ \\
\hline
\end{tabular}

- Rank order by proportion of births over $3500 \mathrm{~g}$.

** Live births only.

Table 3 Trend in distribution by weight of all births in selected countries (\%)

\begin{tabular}{|c|c|c|c|c|c|c|}
\hline Country & Year & $<2500_{g}$ & $2501-3000 \mathrm{~g}$ & $3001-3500 \mathrm{~g}$ & $3501-4000 \mathrm{~g}$ & $>4000 \mathrm{~g}$ \\
\hline NORWAY & $\begin{array}{l}1967-71 \\
1972-4\end{array}$ & $\begin{array}{l}4.8 \\
4.4\end{array}$ & $\begin{array}{l}11 \cdot 8 \\
11 \cdot 7\end{array}$ & $\begin{array}{l}32 \cdot 9 \\
32 \cdot 9\end{array}$ & $\begin{array}{l}34 \cdot 1 \\
34 \cdot 3\end{array}$ & $\begin{array}{l}16 \cdot 4 \\
16 \cdot 7\end{array}$ \\
\hline DENMARK* & $\begin{array}{l}1959 \\
1969-70 \\
1971-2 \\
1973-4\end{array}$ & $\begin{array}{l}6.9 \\
6.0 \\
5.7 \\
6.8\end{array}$ & $\begin{array}{l}18 \cdot 2 \\
14 \cdot 8 \\
14 \cdot 4 \\
17 \cdot 6\end{array}$ & $\begin{array}{l}37 \cdot 3 \\
35 \cdot 9 \\
35 \cdot 6 \\
37 \cdot 1\end{array}$ & $\begin{array}{l}27 \cdot 7 \\
30 \cdot 9 \\
31 \cdot 3 \\
28 \cdot 5\end{array}$ & $\begin{array}{r}9.9 \\
12.5 \\
13.0 \\
10.0\end{array}$ \\
\hline UNITED KINGDOM & $\begin{array}{l}1958 \\
1970\end{array}$ & $\begin{array}{l}6 \cdot 2 \\
6 \cdot 8\end{array}$ & $\begin{array}{l}18 \cdot 0 \\
18 \cdot 9\end{array}$ & $\begin{array}{l}35 \cdot 9 \\
39 \cdot 1\end{array}$ & $\begin{array}{l}27 \cdot 0 \\
26 \cdot 8\end{array}$ & $\begin{array}{l}9 \cdot 3 \\
8 \cdot 3\end{array}$ \\
\hline $\begin{array}{l}\text { USA } \\
\text { ALL BIRTHS }\end{array}$ & $\begin{array}{l}1960 \\
1966 \\
1973\end{array}$ & $\begin{array}{l}7 \cdot 7 \\
8 \cdot 1 \\
7 \cdot 6\end{array}$ & $\begin{array}{l}18 \cdot 4 \\
20 \cdot 9 \\
18 \cdot 2\end{array}$ & $\begin{array}{l}37 \cdot 9 \\
39 \cdot 4 \\
38 \cdot 2\end{array}$ & $\begin{array}{l}26 \cdot 7 \\
24 \cdot 4 \\
27 \cdot 0\end{array}$ & $\begin{array}{l}9 \cdot 0 \\
7 \cdot 1 \\
9 \cdot 0\end{array}$ \\
\hline WHITE BIRTHS & $\begin{array}{l}1960 \\
1966 \\
1973\end{array}$ & $\begin{array}{l}6 \cdot 8 \\
7 \cdot 0 \\
6.4\end{array}$ & $\begin{array}{l}17 \cdot 3 \\
19 \cdot 4 \\
16 \cdot 6\end{array}$ & $\begin{array}{l}38 \cdot 1 \\
39 \cdot 7 \\
38 \cdot 7\end{array}$ & $\begin{array}{l}28 \cdot 2 \\
25 \cdot 1 \\
28 \cdot 8\end{array}$ & $\begin{array}{r}9.6 \\
8.8 \\
10.0\end{array}$ \\
\hline NON-WHITE BIRTHS & $\begin{array}{l}1960 \\
1966 \\
1973\end{array}$ & $\begin{array}{l}12 \cdot 9 \\
13 \cdot 5 \\
13 \cdot 3\end{array}$ & $\begin{array}{l}25 \cdot 3 \\
27 \cdot 5 \\
25 \cdot 8\end{array}$ & $\begin{array}{l}37 \cdot 1 \\
38 \cdot 1 \\
38 \cdot 4\end{array}$ & $\begin{array}{l}18 \cdot 9 \\
17 \cdot 0 \\
18 \cdot 2\end{array}$ & $\begin{array}{l}5.9 \\
3.8 \\
4.4\end{array}$ \\
\hline
\end{tabular}

* In Denmark, repeated changes in classification from 0-499 g, 500-999 g, etc. to 0-500 g, 501-1000 g, etc. and vice versa have occurred. It is estimated that such changes would alter the proportions of neonates in the bands $<1.5 \mathrm{~kg}$ and $1.5-2.0 \mathrm{~kg}$ by about $0.03 \%$ and $0.14 \%$ respectively.

Information from the National Statistical Bureaux of Norway, Denmark, and the USA and from Chamberlain et al. ${ }^{*}$ for the United Kingdom. 
proportion under $2500 \mathrm{~g}$ is also low $(5 \cdot 1 \%)$ and the infant mortality rate is very low $(10.4$ per 1000$)$. There are three problems here that prevent comparison with the Scandinavian countries. Firstly, there is an ethnic difference; secondly, the Japanese data relate to live births only; and, thirdly, there may be a difference in the recording of infant deaths, as the fetal death rate in Japan was 41.8 per 1000 compared with 10.5 per 1000 in Norway.

The first problem is to consider how consistent were the distributions by weight in individual countries? Table 3 shows the serial distributions. In Norway, there was a consistent pattern between 1967 and 1974 despite a significant decline in annual births during that period. This was not so in Denmark, where, after considerable improvement in the distribution between 1959 and 1972, there was a return to earlier patterns in 1973-4 and the birth rate had changed little. Trolle ${ }^{25}$ found an inverse relationship between the annual number of births and the proportion of infants of $2500 \mathrm{~g}$ or less during the post-war 'baby boom' in Denmark, when the proportion of low-birthweight infants declined to $4.6 \%$ compared with $8 \%$ in the early 1940 s.

In England and Wales, where birth weights are not provided regularly, the proportion of births under $2501 \mathrm{~g}$ declined from $7.9 \%$ in 1955 to $7 \cdot 1 \%$ in 1964 concomitantly with an increase in annual births from approximately 680000 to 890000 in 1964 . Then, from 1964 to 1970, a moderate decline in births adversely affected the proportion of low birth weights, which reached $7.5 \%$ in 1970 . No information is available about the distribution by weight of all births between 1955 and 1970, but Chamberlain $^{26}$ and his colleagues confirm a less favourable distribution by weight of all births in 1970 than in 1958.

In the USA a lack of consistency in the pattern of distribution by weight of all births between 1960 and 1973 is also apparent; 1966 showed the lowest proportion of heavy newborn infants together with the highest proportion of infants of low birth weight, while the more favourable distribution pattern of 1960 was more or less regained in 1973. Both white and non-white births were affected similarly by the adverse trend from $1960-6$ and by the more favourable development between 1966 and 1973.

This increase in the birthweight distribution may be partly explained by the increasing age and parity of mothers as the birth rate rises and a similar fall as it declines, but the pattern is not entirely consistent. In Denmark the mean parity was steady at 2.1 between 1970 and 1974 when the birthweight distribution was changing whereas in the USA, mean parity declined year by year from 1960 to 1974 , yet the birthweight distribution shifted upwards and then went down again. By contrast, in Norway parity declined between 1967 and 1974 yet birth weight remained stable. Clearly some other factors have to be considered.

This raises the questions 'Does the birthweight distribution in a country truly reflect the intrauterine growth potential of the mother and child?' and 'Are the majority of pregnancies allowed to come to full term?'

Table 4 shows the increases that can be expected with increased parity. The mean birth weight increases by about $140-150 \mathrm{~g}$ between parity 0 and parity 1 and then by about $50 \mathrm{~g}$ for subsequent pregnancies. An increase in the means of this order

Table 4 Mean increase in birth weight $(g)$ with parity in selected countries

\begin{tabular}{|c|c|c|c|c|c|}
\hline Country & Year & Parity 1 & Parity 2-3 & Parity $3-4$ & Mean birth weight \\
\hline $\begin{array}{l}\text { NORWAY } \\
\text { DENMARK } \\
\text { ENGLAND AND WALES }\end{array}$ & $\begin{array}{l}1967 \\
1970 \\
1935-46 \\
1958\end{array}$ & $\begin{array}{l}140_{\mathrm{g}} \\
150_{\mathrm{g}} \\
145_{\mathrm{g}} \\
140_{\mathrm{g}}\end{array}$ & $\begin{array}{r}40 \mathrm{~g} \\
50_{\mathrm{g}} \\
27_{\mathrm{g}} \\
0 \mathrm{~g}\end{array}$ & $\begin{array}{l}40 \mathrm{~g} \\
50 \mathrm{~g} \\
\overline{0 \mathrm{~g}}\end{array}$ & $\begin{array}{l}3470 \mathrm{~g} \\
3370_{\mathrm{g}} \\
3257_{\mathrm{g}} \\
3332 \mathrm{~g}\end{array}$ \\
\hline UNITED KINGDOM & 1970 & $138 \mathrm{~g}^{*}$ & - & - & $3310_{g}$ \\
\hline SCOTLAND & $1969-73$ & $120 \mathrm{~g}$ & $10 \mathrm{~g}$ & $-20 g$ & \\
\hline $\begin{array}{l}\text { USA } \\
\text { WHITE BIRTHS ONLY }\end{array}$ & $\begin{array}{l}1966 \\
1973\end{array}$ & $\begin{array}{l}40 \mathrm{~g} \\
50 \mathrm{~g}\end{array}$ & $\begin{array}{l}20 g \\
10_{g}\end{array}$ & $\begin{array}{l}10 \mathrm{~g} \\
10 \mathrm{~g}\end{array}$ & $\begin{array}{l}3300 \mathrm{~g} \\
3350 \mathrm{~g}\end{array}$ \\
\hline $\begin{array}{l}\text { NEW YORK STATE } \\
\text { WHITE BIRTHS }\end{array}$ & $\begin{array}{l}1959 \\
1967\end{array}$ & $\begin{array}{l}65 \mathrm{~g} \\
50 \mathrm{~g}\end{array}$ & $\begin{array}{l}30 \mathrm{~g} \\
23 \mathrm{~g}\end{array}$ & $\begin{array}{l}30 \mathrm{~g} \\
22 \mathrm{~g}\end{array}$ & $\begin{array}{l}3372 \mathrm{~g} \\
3344 \mathrm{~g}\end{array}$ \\
\hline
\end{tabular}

Information obtained from the following sources:

Norway: Bjerkedal and Bakketeigie

Denmark: Danish Central Bureau of Statistics

England and Wales: Karn et al 1951 and Butler and Alberman'

United Kingdom: Chamberlain et al. *

Scotland: Lewiss

USA: US Department of Health, Education and Welfare." (Information on median birth weight only, calculated to nearest $10 \mathrm{~g}$ on basis of exact conversion of interval limits for pounds and ounces.) New York State: Selvin and Janerich"

- Increase between parity 1 and all later parities. 
may be an indication that the majority of pregnancies are allowed to proceed to term. In the USA the increase between parity 0 and parity 1 is $50 \mathrm{~g}$ and it is negligible for later pregnancies. This reduced increase in birth weight with parity was noted by Selvin and Janerich ${ }^{27}$ in 1971 . This pattern suggests that American mothers are not allowed to develop their full intrauterine growth potential.

In England and Wales the figures for increase in mean birth weight with parity are not available in detail but the increase between parity 0 and all later births was only $138 \mathrm{~g}$ in 1970 , and in Scotland in 1968-73 the increase between parity 0 and parity 1 was $120 \mathrm{~g}$. With no significant decline in mean parity between 1958 and 1970, and a certain increase in the proportion of second- and third-born infants, mean birth weight declined, as did the proportion of heavy newborn infants. ${ }^{28}$ The distribution pattern by weight of all births in the United Kingdom therefore incompletely reflects the intrauterine growth potential of the mothers.

\section{Discussion}

The largest discrepancy in mean birth weight and distribution by weight of all births observed within one ethnic group was described by Adams and Niswander ${ }^{28}{ }^{29}$ in an investigation of the North American Indian tribes. The proportion of heavy infants ( $3417 \mathrm{~g}$ or more) ranged from $54.5 \%$ in the Cheyenne to $27 \%$ in the Hopi infants, and the proportions of liveborn infants of $2508 \mathrm{~g}$ or less were $4.0 \%$ and $7.5 \%$ respectively. Birth weight was apparently related to food procurement and utilisation habits, and the low birth weight in certain tribes was probably due to the fact that they were living near subsistence level. Mean male stature differed significantly: $174.8 \mathrm{~cm}$ in the Cheyenne compared with $164.5 \mathrm{~cm}$ in the Hopi tribe. In these people, birth weight is therefore an indicator of health and social development.

In the Nordic countries, with their exceptionally high standard of living and with medical care available to every citizen, the proportion of infants of $3500 \mathrm{~g}$ or more ranges from $60 \%$ in Iceland and the Faeroe islands to $50 \%$ in Norway and Sweden and only $38.5 \%$ in Denmark. ${ }^{30}$ Although birth weight is associated with length of gestation there is no evidence that in Iceland the heavy infants had an excess of postterm deliveries over 42 weeks. Mean gestation was similar at $40 \cdot 1$ weeks and some $16.4 \%$ of the Icelandic deliveries were postterm compared with $15 \%$ and $16 \%$ in Norway and Sweden.

Parity is another factor influencing birth weight and the distribution by parity differs significantly in Nordic countries, with an excess of fourth- and later-born infants in Iceland. However, the estimated effect of this factor on mean birth weight is only $15-30 \mathrm{~g}$, whereas the observed discrepancy in mean birth weight between Iceland and Norway and Sweden approaches $100 \mathrm{~g}$. The maternal age range 25-29 is optimal as regards birth weight, and younger mothers give birth to a greater proportion of low-birthweight infants. Less than $25 \%$ of the deliveries in Iceland are to mothers aged 25-29 compared with $35-40 \%$ in Norway, Denmark, and Sweden, where there is a tendency towards postponement of pregnancy among younger women. In Iceland, more than half the deliveries are to women under 25 and more than $17 \%$ to women under 20.

The predominance of heavy newborn infants in Iceland may be partly due to the more rural character of that country. ${ }^{31}{ }^{32}$ The similarity in distribution by weight of all births in Iceland and some of the less urban counties in Norway also supports this. A reduction in deliveries to younger mothers would probably reduce infant mortality in Iceland to eight per 1000 births or less through a reduction in low birth weight.

The larger proportion of infants weighing more than $3500 \mathrm{~g}$ in Norway compared with Denmark is probably also mainly due to the greater predominance of rural areas in Norway, since the two countries do not differ in distribution by maternal age, parity, or increase in birth weight with parity. It seems reasonable to ask whether some particularly adverse factors affecting birth weight predominate in urban Denmark-for example, the growthretarding effect of a previous termination ${ }^{33}$ might be considered. On the basis of age-specific abortion rates in 1975, it has been calculated that legal abortion would be performed in 707 of 1000 women during their reproductive period between the ages of 15 and 49 . Smoking is commoner in urban regions, particularly among young women. The effect of smoking in pregnancy on birth weight is usually of the order of $200-300 \mathrm{~g}^{3435}$ A shift to lower birth weight could also be induced iatrogenically through a more widespread practice of limiting the mother's weight in pregnancy through diet and diuretics. ${ }^{36-38}$ A reduced proportion of heavy newborn infants due to an excessive use of elective delivery seems less likely because induction rates are similarly low in Denmark and Norway: under $15 \%$. However, with an induction rate of just under $16 \%$ in Copenhagen in 1977 (Table 5) there is a shift to birth weights of 2001-3500 g compared with the city of Arhus, where the rate was under $9 \%$ and where there is a striking excess of infants of $3500 \mathrm{~g}$ or more. The proportion of infants weighing $2000 \mathrm{~g}$ or less is higher in both cities compared with the rest of 
Table 5 Elective and instrumental delivery, distribution by weight of all births, and early neonatal plus neonatal mortality in the two largest cities in Denmark in 1974 and 1977

\begin{tabular}{|c|c|c|c|c|c|c|c|c|c|}
\hline & \multicolumn{2}{|c|}{ DELIVERY (\%) } & \multicolumn{2}{|c|}{$\begin{array}{l}\text { MORTALITY } \\
\text { (rates per } 1000 \text { ) }\end{array}$} & \multicolumn{5}{|c|}{ BIRTH WEIGHT (\%) } \\
\hline & Elective & Instrumental & neonatal & Neonatal & $<2000_{8}$ & $2001-2500 \mathrm{~g}$ & $2501-3000 \mathrm{~g}$ & $3000-3500 \mathrm{~g}$ & $>3501 \mathrm{~g}$ \\
\hline \multicolumn{10}{|c|}{ COPENHAGEN } \\
\hline $\begin{array}{l}1974 \\
1977\end{array}$ & $\begin{array}{l}17 \cdot 2 \\
15 \cdot 7\end{array}$ & $\begin{array}{l}16 \cdot 3 \\
20.9\end{array}$ & $\begin{array}{l}6 \cdot 5 \\
3 \cdot 3\end{array}$ & $\begin{array}{l}7 \cdot 4 \\
4 \cdot 4\end{array}$ & $\begin{array}{l}2 \cdot 4 \\
2 \cdot 3\end{array}$ & $\begin{array}{l}5 \cdot 0 \\
5 \cdot 5\end{array}$ & $\begin{array}{l}21 \cdot 0 \\
20 \cdot 2\end{array}$ & $\begin{array}{l}38 \cdot 2 \\
39 \cdot 2\end{array}$ & $\begin{array}{l}33.4 \\
32.8\end{array}$ \\
\hline \multicolumn{10}{|l|}{ ARHUS } \\
\hline $\begin{array}{l}1974 \\
1977\end{array}$ & $\begin{array}{l}9.7 \\
8.3\end{array}$ & $\begin{array}{r}7.8 \\
10.7\end{array}$ & $\begin{array}{l}5 \cdot 9 \\
4 \cdot 5\end{array}$ & $\begin{array}{l}6.5 \\
5.6\end{array}$ & $\begin{array}{l}2 \cdot 2 \\
2 \cdot 3\end{array}$ & $\begin{array}{l}3.9 \\
3.6\end{array}$ & $\begin{array}{l}16 \cdot 3 \\
15 \cdot 0\end{array}$ & $\begin{array}{l}37 \cdot 1 \\
35 \cdot 2\end{array}$ & $\begin{array}{l}40 \cdot 5 \\
43.8\end{array}$ \\
\hline \multicolumn{10}{|c|}{ REMAINING COUNTIES IN DENMARK } \\
\hline $\begin{array}{l}1974 \\
1977\end{array}$ & $\begin{array}{l}14 \cdot 7 \\
14 \cdot 7\end{array}$ & $\begin{array}{l}13 \cdot 3 \\
16 \cdot 4\end{array}$ & $\begin{array}{l}7.2 \\
4.9\end{array}$ & $\begin{array}{l}8 \cdot 3 \\
5 \cdot 8\end{array}$ & $\begin{array}{l}2.4 \\
1.9\end{array}$ & $\begin{array}{l}4 \cdot 4 \\
4 \cdot 1\end{array}$ & $\begin{array}{l}17 \cdot 3 \\
17 \cdot 0\end{array}$ & $\begin{array}{l}37.0 \\
36.7\end{array}$ & $\begin{array}{l}38.9 \\
40.3\end{array}$ \\
\hline
\end{tabular}

Caesarean sections rose from 8.2 to $10.6 \%$ in Copenhagen, from 3.6 to $4.8 \%$ in Arhus, and from 6.1 to $8.1 \%$ in the remaining counties in Denmark.

Table 6 Mortality by birth weight (g) in Copenhagen and Arhus, 1977 (rates per 1000)

\begin{tabular}{|c|c|c|c|c|c|c|}
\hline & \multicolumn{3}{|c|}{ Early neonatal } & \multicolumn{3}{|c|}{ Neonatal } \\
\hline & $<2000$ & $2001-3500$ & $>3500$ & $<2000$ & $2001-3500$ & $>3500$ \\
\hline COPENHAGEN & 86.9 & 1.9 & 0.5 & $113 \cdot 0$ & 2.4 & $1 \cdot 1$ \\
\hline ARHUS & $146 \cdot 3$ & 1.9 & 0.3 & $189 \cdot 0$ & $2 \cdot 4$ & $0 \cdot 3$ \\
\hline DENMARK & $158 \cdot 5$ & $2 \cdot 4$ & 0.7 & 180.9 & $3 \cdot 1$ & $1 \cdot 1$ \\
\hline
\end{tabular}

In Copenhagen, $95 \%$ of the deliveries took place in maternity wards in hospital, $0.2 \%$ in other wards, $4 \cdot 1 \%$ in maternity homes, $0.9 \%$ at home. In Arhus, $50.3 \%$ took place in maternity wards, $22.9 \%$ in other wards, $25.9 \%$ in maternity homes, $0.9 \%$ at home.

Denmark. The two cities differ in distribution by maternal age, with an excess of younger mothers in Copenhagen.

This significant shift to lower birth weight with induction rates as low as $15-17 \%$ suggests that our uncertainty about length of gestation is probably greater than has hitherto been assumed. ${ }^{39}{ }^{40}$ The optimal induction rate-that which confers minimal mortality without adversely affecting the distribution pattern by weight through a reduction in infants with minimal risk of mortality - is probably considerably lower than has previously been assumed.

The comparison of weight-specific neonatal mortality in Copenhagen with that in Arhus in 1977 is most interesting (Table 6). In Arhus, mortality was lower than in Copenhagen for infants weighing more than $3500 \mathrm{~g}$. For those between $2001 \mathrm{~g}$ and $3500 \mathrm{~g}$ the rates were similar; below $2000 \mathrm{~g}$ they were higher. The extremely low rates for infants weighing under $2000 \mathrm{~g}$ in Copenhagen are due to the very high proportion of hospital deliveries in that city. The low mortality of heavy newborn infants in Arhus accords with Baird's statement ${ }^{41}$ : 'the present mothers are younger and healthier than a generation ago and for this reason the danger of prolonged pregnancy is less'.

The present distribution by weight of all births in Britain is not known but low birth weight is routinely recorded. Between 1955 and 1974 the proportion of infants weighing 2000-2500 g remained unchanged at $5 \%$ while that of those weighing less than $2000 \mathrm{~g}$ declined from $2.9 \%$ to $2 \%$. The lack of decline in the weight group 2000-2500 g could well be related to the concomitant rise in rates of induction: from about $13 \%$ in the early $1960 \mathrm{~s}^{42}$ to about $40 \%$ in $1974-5$. The specific effect on birth weight of high rates of induction has been shown in Cardiff, where there was an adverse effect on birth weight through a reduction in the mean period of gestation. ${ }^{43}$ The fall in birth weight was considered secondary to the fall in gestational age. This report from Cardiff is of particular interest because high rates of induction could also affect the discrepancy in birth weight between the sexes through the reduction in gestational age, since male and female firstborn infants differ significantly in gestational age distribution, with a striking excess of female postterm deliveries. ${ }^{19} 20$

The widespread practice of restricting a mother's weight in pregnancy through diet and diuretics, and an extremely high frequency of elective deliveries, have characterised the USA for several decades. ${ }^{44} 45$ With the virtual elimination of increasing birth weight with parity in the USA (Table 4), a reduction would also be expected in the association between birth weight and birth order in individual families. ${ }^{46-50}$ This elimination has probably obscured the adverse effect on birth weight of the significant decline in mean parity from 2.92 in 1962 to 2.13 in 1973 in the USA. 
The inverse relationship between the proportions of heavy newborn infants and low-birthweight neonates can be seen from the following figures in this investigation: low-birthweight infants increase from less than $4 \%$ when $60 \%$ are heavy newborns, to $7 \%$ when less than $40 \%$ weigh $3500 \mathrm{~g}$ or more, and reach $12 \%$ when $26.9 \%$ weigh $3500 \mathrm{~g}$ or more. With the present variety of uncontrollable and non-genetic factors influencing weight at birth, the present distribution pattern in several countries incompletely reflects this relationship. For example, in Japan, where the proportion of heavy newborn infants is as low as $23 \%$, only $5 \cdot 1 \%$ are of low birth weight. This strikingly low proportion of liveborn infants weighing $2500 \mathrm{~g}$ or less is related to the high ratio of fetal to neonatal deaths in Japan, where infant deaths constitute only one-fifth of the total early and late fetal loss. . $^{30}$

Social class is a powerful determinant of birth weight. The present social class differential in birth weight is of the order of $200-300 \mathrm{~g} .{ }^{1126}$ s1-53 With high rates of induction, there is reason to believe that those most at risk of being induced are the uncomplicated 'high-birthweight' pregnancies of upper and middle class women. ${ }^{424455}$ These women usually have easier access to innovation in medical practice than those in the lower social classes. High rates of induction could therefore be expected to tend to diminish the social class differential through reducing the proportion of heavy infants in 'upper and middle class' families. However, the social class differential has remained the same or even increased. ${ }^{11}{ }^{11}$ This is due to the predominance in the lower socioeconomic categories of young mothers with unwanted illegitimate pregnancies, as well as a high proportion of mothers who smoked in pregnancy and a persistently lower use of the health services. ${ }^{53} 5857$

In assessing the importance of changes in the distribution by weight, it is therefore important to take into consideration the distribution by social class. In Denmark in 1971-4, there was a shift towards lower birth weight with a reduction in heavy newborn infants in particular accompanied by a $5 \%$ decrease in the number of births. But this decrease was the result of a 7\% reduction in births in social classes I and II, while in classes IV and V there was an increase of $8 \%$. In highly urbanised countries such as Denmark, Britain, and the USA, minor changes in the annual number of births tend to be associated with changes in the distribution by birth weight, which suggests that rapidly changing differential fertility by social class is a characteristic of these countries. In sparsely populated and less urbanised countries like Norway, these rapid changes are not observed.
Reprints from Dr. L. F. Saugstad, Institute of Occupational Health, Gydas Vei 8, Oslo 3 (postboks 5387), Norway.

\section{References}

${ }^{1}$ United Nations Association. United Nations Demographic Yearbook 1975. New York: UN: 753.

${ }^{2}$ US Department of Commerce. Statistical Abstract of the United States 1960-75. Washington: Bureau of the Census, 1976.

${ }^{3}$ US Department of Health, Education and Welfare. Vital Statistics of the United States 1960-74. Vol. I-Natality. Washington: USDHEW, 1975.

${ }^{4}$ New York State Department of Health. Birthweight, Gestation and Infant Mortality by Race, Sex, and Age at Death. New York State (excluding New York City) 1968-70. Albany, New York: NYSDH, 1976.

${ }^{5}$ Central Statistical Office. Annual Abstract of Statistics 1955-76. London: HMSO, 1978.

${ }^{6}$ Ministry of Health. On the State of the Public Health. Annual Reports of the Chief Medical Officer for the years 1955-67. London: HMSO.

${ }^{7}$ Department of Health and Social Security. On the State of the Public Health. Annual Reports of the Chief Medical Officer for the years 1968-75. London: HMSO.

-Vital Statistics 1967-75. Statistiske Meddelelser, Danmarks Statistik, København 1969-1977.

${ }^{9}$ Medicinsk Fødselsstatistik, 1970: Medicinalstatistiske meddelelser 1973: 1, Sundhedsstyrelsen, p. 95.

${ }^{10}$ Medicinsk Fødselsstatistik 1972, Medicinalstatistiske meddelelser, 1975: 1, Sundhedsstyrelsen, p. 82.

${ }^{11}$ Medicinsk Fødselsstatistik 1974, Medicinalstatistiske meddelelser, 1976: 4, Sundhedsstyrelsen, p. 72.

${ }^{12}$ National Central Bureau of Statistics, Iceland. Population and Vital Statistics in Iceland 1911-1960. Reykjavik: NCBSI.

${ }^{13}$ National Central Bureau of Statistics, Iceland. Population and Vital Statistics in Iceland 1961-1970. Reykjavik: NCBSI.

${ }^{14}$ Nordic Medico-Statistical Committee. Information on distribution by weight of all births in Iceland 1972. Plenary session, July 1977.

${ }^{15}$ Central Bureau of Statistics. Trend of mortality and causes of death in Norway 1865-1955. Oslo: CBS, 1961: 246.

${ }^{16}$ Central Bureau of Statistics. Infant Mortality in Norway 1901-1963. Oslo: CBS, 1966: 74.

${ }^{17}$ Central Bureau of Statistics. Fetal and Infant Mortality 1969-1972. Oslo: CBS, 1975: 107.

${ }^{18}$ Bjerkedal T, Bakketeig L. Medical Registration of Births in Norway during the 5-year Period 1967-71. Bergen: University of Bergen Institute of Hygiene and Social Medicine, 1975: 71.

${ }^{19}$ National Central Bureau of Statistics, Oslo. Medical Registration of Births in Norway 1972-1976.

${ }^{20}$ National Board of Health and Welfare. Medical Birth Registration in 1973 and 1974. Sveriges Officiella Statistik, Serie HS 1977: 16 Appendix, Stockholm.

${ }^{21}$ Befolkningsförändringar 1968-1975, Del 3, Hela riket och länen. Sveriges Officiella Statistik, Stockholm.

${ }^{22}$ Historisk Statistik för Sverige, Del 1, 1720-1967. Andra Upplagan 1969, Sveriges Officiella Statistik, Almänna Förlaget.

${ }^{23}$ SAREC report: Birth-weight Distribution-an Indicator of Social Development. Report from a Sarec/WHO Workshop. Stockholm: Swedish Agency for Research Cooperation with Developing Countries, 1978.

${ }^{24}$ Nordic Statistical Secretariat. Yearbook of Nordic Statistics 1978, vol. 17. Stockholm: Norstedts Tryckeri: 355. 
${ }^{25}$ Trolle D. Stillbirth and mortality during first week of life from an obstetrical point of view. In: Infant and perinatal mortality in Denmark. Mathiessen PC, Trolle D, Zachau-Christiansen A, ed. National Center of Health Statistics Series 3 No. 9. Washington: USDHEW, 1967.

${ }^{26}$ Chamberlain R, Chamberlain G, Howlett B, Claireaux A. British births 1970 vol. 1. London: Heinemann Medical, 1975: 278.

${ }^{27}$ Selvin S, Janerich DT. Four factors influencing birth weight. Br J Prev Soc Med 1971; 25: 12-6.

${ }^{28}$ Adams MS, Niswander JD. Birth weight of North American Indians. Hum Biol 1968; 40: 226-34.

${ }^{29}$ Adams MS, Niswander JD. Birth weight of North American Indians: a correction and simplification. Hum Biol 1973; 45: 351-7.

${ }^{30}$ Saugstad LF. Birthweight of children. Clin Genet 1980; 17: 84-5.

${ }^{31}$ Drake M. Population and society in Norway 1735-1865. Cambridge Studied in Economic History. Cambridge: Cambridge University Press, 1969: 255.

${ }^{32}$ Snaedal G, Biering G, Sigvaldason H. Obstetric and perinatal medicine in Iceland 1881-1971 with a detailed report on deliveries in Iceland 1972-74. Acta Obstet Gynecol Scand (Suppl) 1975; 45: 47.

${ }^{33}$ Belsey MA et al. Gestation, birth weight and spontaneous abortion in pregnancy after induced abortion. Report of Collaborative Study by WHO Task Force on Sequelae of Abortion. Lancet 1979; i: 142-5.

${ }^{34}$ Gruenwald P. Growth and maturation of the foetus and its relationship to perinatal mortality. In: Perinatal problems. Butler NR, Alberman ED, ed. London: Livingstone, 1962: 141-62.

${ }^{35}$ Gruenwald $P$. The placenta and its maternal supply line. Effect of insufficiency on the foetus. Lancaster: MTP, 1975: 366.

${ }^{36}$ Campbell DM, MacGillivray I. The effect of a low calorie diet or a thiazid diuretic on the incidence of pre-eclampsia and on birth weight. Br J Obstet Gynaecol 1975; 82: 572-7.

${ }^{37}$ Blumenthal I. Diet and diuretics in pregnancy and subsequent growth of offspring. Br Med J 1976; i: 733 .

${ }^{38}$ National Academy of Sciences. Maternal nutrition and the course of pregnancy. Washington: National Research Council, 1970: 241.

${ }^{39}$ Lind T, Billewicz WZ. A point-scoring system for estimating gestational age from examination of amniotic fluid. Br J Hosp Med 1971; 5: 681-5.
${ }^{40}$ Billewicz WZ, Thomson AM. Birthweights in consecutive pregnancies. J Obstet Gynaecol Br Commonwealth 1973; 80: 142-5.

${ }^{41}$ Baird D. Induction of labour. Br Med J 1976; i: 896.

${ }^{42}$ Richards MPM. The induction and acceleration of labour: some benefits and complications. Early Human Development 1977; 1: 3-17.

${ }^{43}$ Newcombe R, Chalmers I. Changes in distribution of gestational age and birth weight among first born infants of Cardiff residents. $\mathrm{Br}$ Med J 1977; ii: 825-6.

${ }^{44}$ Niswander KR, Patterson RJ. Hazards of elective induction of labour. Obstet Gynecol 1963; 22: 228-33.

${ }^{45}$ Blacow M, Smith MN, Graham M, Wilson RG. Induction of labour. Lancet 1975; i: 217.

${ }^{46}$ Hsia DYY. Birthweight in cystic fibrosis of the pancreas. Ann Hum Genet 1959; 23: 289-99.

${ }^{47}$ Robson EB. The genetics of birthweight. In: Human Growth, vol. 1 Tanner E, ed. London: Livingstone, 1978: 285-97.

${ }^{48}$ Rothman KJ, Pueschel SN. Birthweight of children with phenylketonuria. Pediatrics 1976; 58: 842-4.

${ }^{49}$ Saugstad LF. Birthweight in Phenylketonuria. Pediatrics 1980; 65: 190-2.

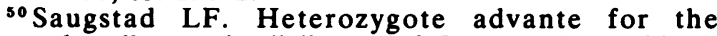
phenylketonuria allelle. J Med Genet 1977; 14: $20-4$.

${ }^{51}$ Matthiessen PC. The influence of birth weight on the stillbirth and the neonatal mortality rate. London: International Union for the Scientific Study of Population, 1969: 351-9.

${ }^{32}$ Lewis AF. 1977. Personal communication.

${ }^{53}$ Saugstad LF. 'Domestication of man' within reach in Scandinavia? (in press).

${ }^{54}$ Niswander KR, Gordon $M$. Women and their pregnancies. The collaborative perinatal study. Philadelphia: WB Saunders, 1972.

${ }^{55}$ Richards MPM. Innovation in medical practice: obstetricians and the induction of labour in Britain. Soc Sci Med 1975; 9: 595-602.

${ }^{56}$ Dutton DB. Explaining the low use of health services by the poor: costs, attitudes, or delivery systems? Am Sociol Rev 1978; 43: 348-68.

${ }^{57}$ Morris JN. Social inequalities undiminished. Lancet 1979 ; i: $87-90$. 